\title{
C-reactive protein exerts angiogenic effects on vascular endothelial cells and modulates associated signalling pathways and gene
} expression

\author{
Marta M Turu ${ }^{\dagger 1,2}$, Mark Slevin ${ }^{\dagger 2,3}$, Sabine Matou ${ }^{\dagger 3}$, David West ${ }^{4}$, \\ Cristina Rodríguez ${ }^{2}$, Ana Luque ${ }^{1,2}$, Marta Grau-Olivares ${ }^{5}$, Lina Badimon², \\ Jose Martinez-Gonzalez ${ }^{2}$ and Jerzy Krupinski* ${ }^{*} 1,2$
}

\author{
Address: ${ }^{1}$ Department of Neurology, University Hospital of Bellvitge (HUB), Fundació IDIBELL, Barcelona, Spain, ${ }^{2}$ Centro de Investigación \\ Cardiovascular, CSIC-ICCC, Hospital de la Santa Creu i Sant Pau, Barcelona, Spain, ${ }^{3}$ School of Biology, Chemistry and Health Science, Manchester \\ Metropolitan University, Manchester, UK, ${ }^{4}$ University of Liverpool, Liverpool, L69 7ZB, UK and ${ }^{5}$ Hospital Sagrat Cor, Barcelona, Spain \\ Email: Marta M Turu - marta.miguel@gmail.com; Mark Slevin - m.a.slevin@mmu.ac.uk; Sabine Matou - s.matou@mmu.ac.uk; \\ David West - westie@liverpool.ac.uk; Cristina Rodríguez - crodriguez@csic-iccc.org; Ana Luque - anabaena2@hotmail.com; Marta Grau- \\ Olivares - ma.aslevin@mmu.ac.uk; Lina Badimon - Ibadimon@csic-iccc.org; Jose Martinez-Gonzalez - jmartinez@csic-iccc.org; \\ Jerzy Krupinski* - krupinski@csub.scs.es \\ * Corresponding author †Equal contributors
}

Published: 2 September 2008

BMC Cell Biology 2008, 9:47 doi:10.1 186/147/-2/21-9-47

This article is available from: http://www.biomedcentral.com/l47|-2/21/9/47

(C) 2008 Turu et al; licensee BioMed Central Ltd.

This is an Open Access article distributed under the terms of the Creative Commons Attribution License (http://creativecommons.org/licenses/by/2.0), which permits unrestricted use, distribution, and reproduction in any medium, provided the original work is properly cited.
Received: 15 February 2008

Accepted: 2 September 2008

\begin{abstract}
Background: Formation of haemorrhagic neovessels in the intima of developing atherosclerotic plaques is thought to significantly contribute to plaque instability resulting in thrombosis. C-reactive protein (CRP) is an acute phase reactant whose expression in the vascular wall, in particular, in reactive plaque regions, and circulating levels increase in patients at high risk of cardiovascular events. Although CRP is known to induce a pro-inflammatory phenotype in endothelial cells (EC) a direct role on modulation of angiogenesis has not been established.

Results: Here, we show that CRP is a powerful inducer of angiogenesis in bovine aortic EC (BAEC) and human coronary artery EC (HCAEC). CRP, at concentrations corresponding to moderate/high risk $(\mathrm{I}-5 \mu \mathrm{g} / \mathrm{ml})$, induced a significant increase in proliferation, migration and tube-like structure formation in vitro and stimulated blood vessel formation in the chick chorioallantoic membrane assay (CAM). CRP treated with detoxi-gel columns retained such effects. Western blotting showed that CRP increased activation of early response kinase-I/2 (ERKI/2), a key protein involved in EC mitogenesis. Furthermore, using TaqMan Low-density Arrays we identified key pro-angiogenic genes induced by CRP among them were vascular endothelial cell growth factor receptor-2 (VEGFR2/KDR), platelet-derived growth factor (PDGF-BB), notch family transcription factors (NotchI and Notch3), cysteine-rich angiogenic inducer 6I (CYR6I/CCNI) and inhibitor of DNA binding/differentiation-I (IDI).
\end{abstract}

Conclusion: This data suggests a role for CRP in direct stimulation of angiogenesis and therefore may be a mediator of neovessel formation in the intima of vulnerable plaques. 


\section{Background}

Atherosclerosis is the underlying cause of ischemic cardiovascular and cerebrovascular diseases [1-3]. Unstable carotid atherosclerotic plaques can undergo thrombotic complications and trigger acute clinical events [4-6]. In atherosclerotic plaques angiogenesis allows the formation of new microvessels to maintain oxygen and nutrient supply for vascular cells. Such processes are potenciated by different molecules secreted by vascular and inflammatory cells [5]. Neovessel growth occurs in active regions of atherosclerotic lesions undergoing remodelling. Our previous studies have demonstrated specific molecular deregulation occurring in these regions, consistent with the promotion of angiogenesis. The new vessels of atherosclerotic lesions may be a focus of instability, since they facilitate the infiltration of inflammatory cells and due to their tendency to leak, may produce haemorrhagic complications [5,7-9]. In a previous study using protein microarrays, we have identified regulation of potentially proangiogenic proteins associated with haemorrhagic vessels in unstable plaques among them c-Jun N-terminal kinase (JNK) and c-src [10].

The role of CRP modulating of angiogenesis in developing atherosclerotic lesions has not been investigated. CRP is an acute-phase reactant expressed during active inflammation [11-16]. Inflammation, the key regulator of CRP synthesis, plays an important role in atherothrombotic cardiovascular and cerebrovascular disease [2]. CRP consists of five identical non-covalently associated and nonglycosylated 23-kDa subunits arranged symmetrically around a central pore and it is synthesized mainly in the liver under the control of interleukin-6 (IL-6) $[17,18]$, although it is also found in other tissues including carotid atherosclerotic plaques $[5,19,20]$. CRP represents one of the strongest independent predictors of symptomatic atherothrombosis and vascular death [21-23] and predicts progression of atherosclerosis [24]. In response to acutephase stimuli, plasma CRP concentration can increase rapidly and dramatically up to 100-fold [25]. CRP levels are increased in patients at moderate- (1 to $3 \mu \mathrm{g} / \mathrm{ml})$ and high-risk $(>3 \mu \mathrm{g} / \mathrm{ml})$ of future cardiovascular events [21].

Although, originally CRP was suggested to be purely a biomarker, recent studies have pointed that it may in fact be a direct mediator of atherosclerosis [26]. Indeed, CRP elicits multiple effects on the vascular wall favouring a proatherosclerotic phenotype. These include attraction of monocytes, mediation of low-density lipoproteins (LDL) uptake by macrophages $[27,28]$ reduction in nitric oxide (NO) release of human EC [29,30], up-regulation of adhesion molecules [31], stimulation of vascular smooth muscle cell (VSMC) proliferation and migration [32], increasing matrix metalloproteinase (MMP) expression in EC and macrophages [33-35], activating the complement system [36] and inducing plasminogen activator inhibitor-1 (PAI-1) expression and activity in human aortic EC [37]. With regard to CRP effects on EC, published studies are somewhat controversial. CRP has been shown to promote production of the pro-angiogenic molecules such as endothelin-1 (ET-1) and IL-6 in human saphenous vein EC [31], and activate NF- $\kappa B$ signalling through the CD32 receptor [38]. In contrast, other studies suggested that EC activation by CRP was due to contamination of the commercially obtained protein with lipopolysaccharide (LPS) and/or sodium azide $[39,40]$.

As we have previously demonstrated increased CRP expression in unstable highly vascularized regions of carotid lesions, we decided to investigate the angiogenic properties of this molecule. Here we show that native CRP and not potentially contaminating LPS or azide is strongly angiogenic both in vitro and in vivo, and activates the expression of some important pro-angiogenic genes in endothelial cells.

\section{Results \\ Chemotaxis was induced by CRP in both HCAEC and BAEC}

Both native and CRPdt significantly increased chemotaxis of HCAEC with a maximum effect at $5 \mu \mathrm{g} / \mathrm{ml}$ following CRPdt treatment (approximately 290\% over controls; $p<$ 0.01) (Figure 1A). CRP also induced a significant increase in chemotaxis of BAEC at similar concentrations with a maximum response at $5 \mu \mathrm{g} / \mathrm{ml} \mathrm{CRP} \mathrm{(approximately} 175 \%$ over controls; $p<0.001$, data not shown). FGF-2 (25 ng/ $\mathrm{ml})$ was used as a positive control. LPS alone $(1 \mathrm{ng} / \mathrm{ml})$ had no effect on cell migration. Blocking experiments were performed with the anti-CRP antibody (1:5) to ensure that the effect was due to the CRP protein itself. The increase in chemotaxis induced by CRPdt was significantly reduced following the pre-incubation with antibody. (Figure 1B)

\section{CRP stimulated BAEC but not HCAEC proliferation}

A significant increase in BAEC proliferation (approximately $40 \%$ over controls; $p<0.05)$ was seen $72 \mathrm{~h}$ after treatment with $1 \mu \mathrm{g} / \mathrm{ml}$ native CRP (Figure 2). Treatment of CRP with detoxi-gel columns (CRPdt) did not ameliorate proliferation, and in fact, a further increase was shown (approximately $80 \%$ over controls; $p<0.01$ ). At 5 $\mu \mathrm{g} / \mathrm{ml}$ CRPdt also produced a significant effect. Endotoxin (LPS $1 \mathrm{ng} / \mathrm{ml}$ ) alone had no effect on BAEC proliferation. CRP did not affect proliferation of HCAEC at any of the concentrations tested (data not shown).

\section{CRP induced tube-like structure formation in HCAEC and BAEC}

CRP induced the formation of tube-like structures in growth factor depleted matrigel in both HCAEC and 

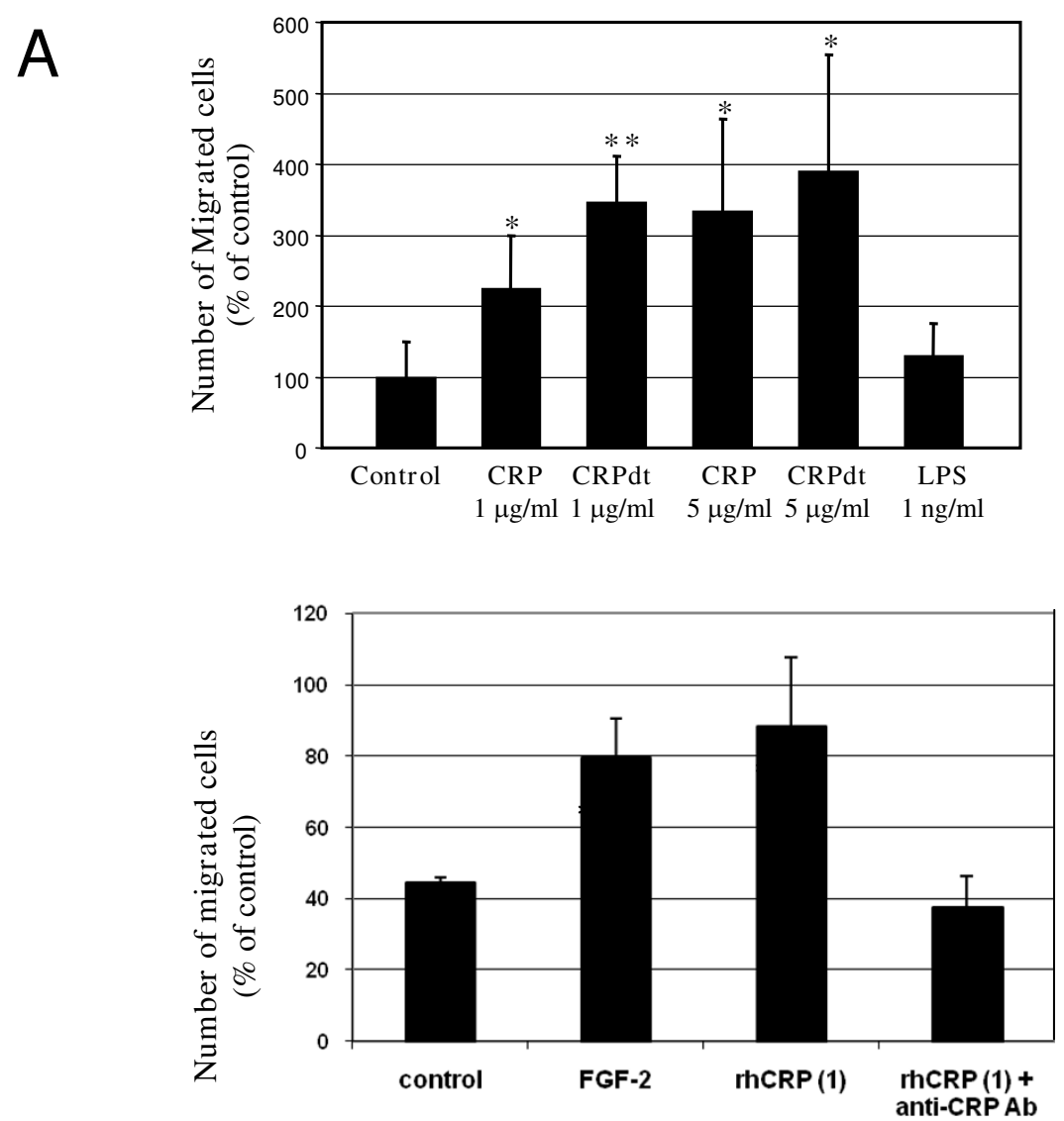

$(1: 5)$

\section{Figure I}

A, CRP induced a significant increase in chemotaxis in HCAEC. Cell migration was measured using a modified Boyden chamber as described in Methods. The effect of $\mathrm{I}-5 \mu \mathrm{g} / \mathrm{ml}$ CRP (non-detoxified and detoxified CRP [CRPdt]) on HCAEC chemotaxis is shown. Endotoxin alone (LPS; I ng/ml) had no effect. B, Migration experiments were performed at least twice in triplicate wells. B, rhCRP $(\mathrm{I} \mu \mathrm{g} / \mathrm{ml})$ induced migration as compared with control and $\mathrm{rhCRP}(\mathrm{I} \mu \mathrm{g} / \mathrm{ml})+\mathrm{antiCRP} \mathrm{Ab}(\mathrm{I}: 5)$. * and ** indicate a statistically significant difference compared with the control cells $(p>0.05$ and 0.00 I respectively).

BAEC. Tube formation increased in CRP-treated HCAEC by approximately 4 fold at $1-5 \mu \mathrm{g} / \mathrm{ml}(p<0.01)$. (Figure 3). CRPdt and non-detoxified CRP produced a similar effect. LPS ( $1 \mathrm{ng} / \mathrm{ml})$ had no effect. Similar results were obtained in BAEC, in this case the maximal effect was observed at 1 and $5 \mu \mathrm{g} / \mathrm{ml}$ with CRPdt (approximately a 3 -fold increase; $p \leq 0.01$ ) which are lower than showed by FGF-2 treated cells (positive control)(Figure 4 and Figure 5A). Tube formation was significantly inhibited in cells pre-incubated with anti-CRP antibody, $\mathrm{p}<0.01$ (Figure 5B).

\section{CRP stimulated blood vessel formation in the CAM assay}

CRPdt $(5 \mu \mathrm{g} / \mathrm{ml})$ was chosen following our in vitro studies for analysis of angiogenesis in the CAM assay. CRPdt induced blood vessel formation after 7 days treatment compared with the control, as evidenced by the spoke wheel pattern formation (mean value of 2, from 15 replicates, $\mathrm{p}<0.001$; Figure 6A, control and B, CRPdt). FGF-2 $(25 \mathrm{ng} / \mathrm{ml})$ was used as a positive control and gave a strong positive response (Figure 6C). Membranes treated with the equivalent concentration of sodium azide or with LPS ( $1 \mathrm{ng} / \mathrm{ml}$ ) alone showed no significant response (data not shown).

\section{CRP stimulated angiogenic sprouting of aortic tissue}

We used a rat aortic ring assay to examine the effects of CRP on angiogenesis. We showed that CRP stimulated microvessel sprouting from the cultured aortic rings (area occupied by sprout microvessels of aortic rings; control, $2,3 \pm 0,3 ; \mathrm{CRP}(1 \mu \mathrm{g} / \mathrm{ml}) 10,5 \pm 0,8 ; \mathrm{FGF}-2(25 \mathrm{ng} / \mathrm{ml})$, $11,1 \pm 0,03 ; \mathrm{p}<0.01)$. (Figure 7 ) 


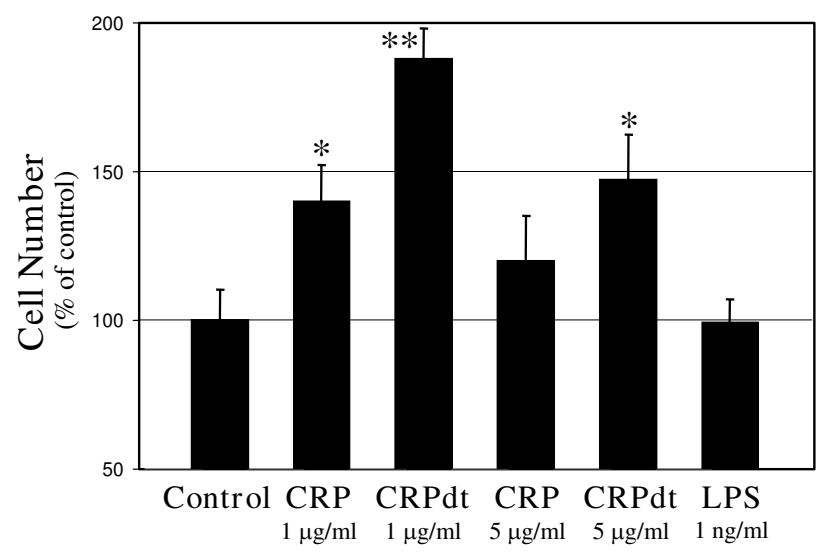

Figure 2

CRP stimulated BAEC proliferation. The effect of I-5 $\mu \mathrm{g} / \mathrm{ml}$ CRP (non-detoxified and detoxified CRP [CRPdt]) for $72 \mathrm{~h}$ on $B A E C$ proliferation is shown. Experiments were repeated at least twice in triplicate wells. * and ** indicate a statistically significant difference compared with the control cells $(p>$ 0.05 and 0.001 respectively).

\section{CRP induces endothelial cell invasion in a 3D-Matrige ${ }^{\mathrm{TM}}$ matrices}

We investigated the effects of CRPdt on invasion/migration using HCAECs in 3D-Matrigel ${ }^{\mathrm{TM}}$ matrices. Unstimulated HCAEC (control) showed a low level of network formation (Figure 8). However, when an HCAEC network was preformed in Matrigel ${ }^{\mathrm{TM}}$ in the presence of FGF-2 (25 $\mathrm{ng} / \mathrm{ml})$, CRPdt $(1 \mathrm{ug} / \mathrm{ml})$ stimulated an invasion into a second layer of 3D-Matrigel ${ }^{\mathrm{TM}}$ matrices (Figure 8, arrows).

\section{CRP increased the phosphorylation of ERKI/2}

Phosphorylation of ERK1/2 is a key event associated with mitogenesis in vascular $\mathrm{EC}$, and we have previously shown that its inhibition in BAEC is sufficient to prevent growth factor stimulation of angiogenesis [41]. Semi-confluent ECs (BAEC and HCAEC) cultured in SPM for $48 \mathrm{~h}$ were treated with CRP/CRPdt ( 1 or $5 \mu \mathrm{g} / \mathrm{ml}$ ) or FGF-2 (25 $\mathrm{ng} / \mathrm{ml}$; positive control), and incubated for $8 \mathrm{~min}$ (optimum time for phosphorylation as determined in our previous published studies) [41]. Both CRP and CRPdt notably increased phosphorylation of ERK1/2 in HCAEC (Figure 9) and BAEC (data not shown). Neither purified endotoxin nor sodium azide induced ERK1/2 activation (data not shown).

\section{CRP stimulated gene expression of multiple angiogenic markers}

HCAEC were treated for various times with CRP (see methods). Table 1 shows results obtained by quantitative TaqMan low-density array analysis corresponding to 6 genes involved in angiogenesis that increased more than 1.5 fold in CRP treated HCAEC compared to the control azide-only cells (1.0) in two separate experiments. These genes were two members of the Notch family (Notch1 and Notch3), VEGF receptor-2 (KDR), the main VEGF receptor, the mitogen platelet derived growth factor-beta (PDGF $\beta$ ), cysteine-rich 61 (CYR61), which stimulates angiogenesis following integrin binding, and inhibitor of DNA binding 1 (ID1). No studied angiogenic genes were down-regulated compared with control cells.

\section{Discussion}

Several studies have suggested CRP as biomarker for cardiovascular and cerebrovascular diseases $[13,14]$; however, this protein also seems to be a mediator of atherosclerosis $[26,27]$. Angiogenesis is a recognised mechanism involved in the development of complicated atherosclerotic plaques and previous studies have provided controversial data regarding the possible angiogenic or antiangiogenic effect of CRP. In this work, we have examined the hypothesis that CRP might play a role in modulating angiogenesis, and as such, its presence in vascular regions of developing arterial plaques may be implicated in their progression to unstable, haemorrhagic lesions prone to rupture. Our data shows that CRP, at concentrations commonly found in the circulation of patients with active carotid disease, is highly pro-angiogenic both in vitro, and in vivo. Furthermore, CRP activates cell signalling and increases expression of key genes associated with angiogenesis.

In order to show that the effects of CRP were due to CRP itself and not other components, we have attempted to address the controversy surrounding the influence of "contaminants" present in commercial preparations of CRP. Notably, Pepys et al. demonstrated that pure natural human CRP free from endotoxins and azide, was not proinflammatory to macrophages in vitro [42]. More specifically, inhibition of HUVEC cell proliferation, eNOS gene expression and increased apoptosis measured by activation of caspase-3/9, have been attributed to the presence of azide in CRP preparations. Similarly, contaminating LPS was shown to increase IL-8, ICAM-1 and MCP-1 gene expression $[39,40]$. It is worthy of note, however, that the effects of azide were demonstrated at concentrations $(0.0025 \%)$ equal to those produced by administration of $50 \mu \mathrm{g} / \mathrm{ml}$ CRP. In our study, concentrations of CRP and therefore azide used in the majority of experiments were much lower and in fact, had no significant effects on cell growth and gene expression as demonstrated in the TaqMan microarrays. Even so, this highlights the importance of using satisfactory controls when conducting this type of assays. In our studies, all of the controls, used for comparison with CRP tests, contained equivalent amounts of azide so that direct comparisons were able to be made. Finally, in our study, we show that the treatment of CRP with detoxi-gel columns did not negate the pro-ang- 

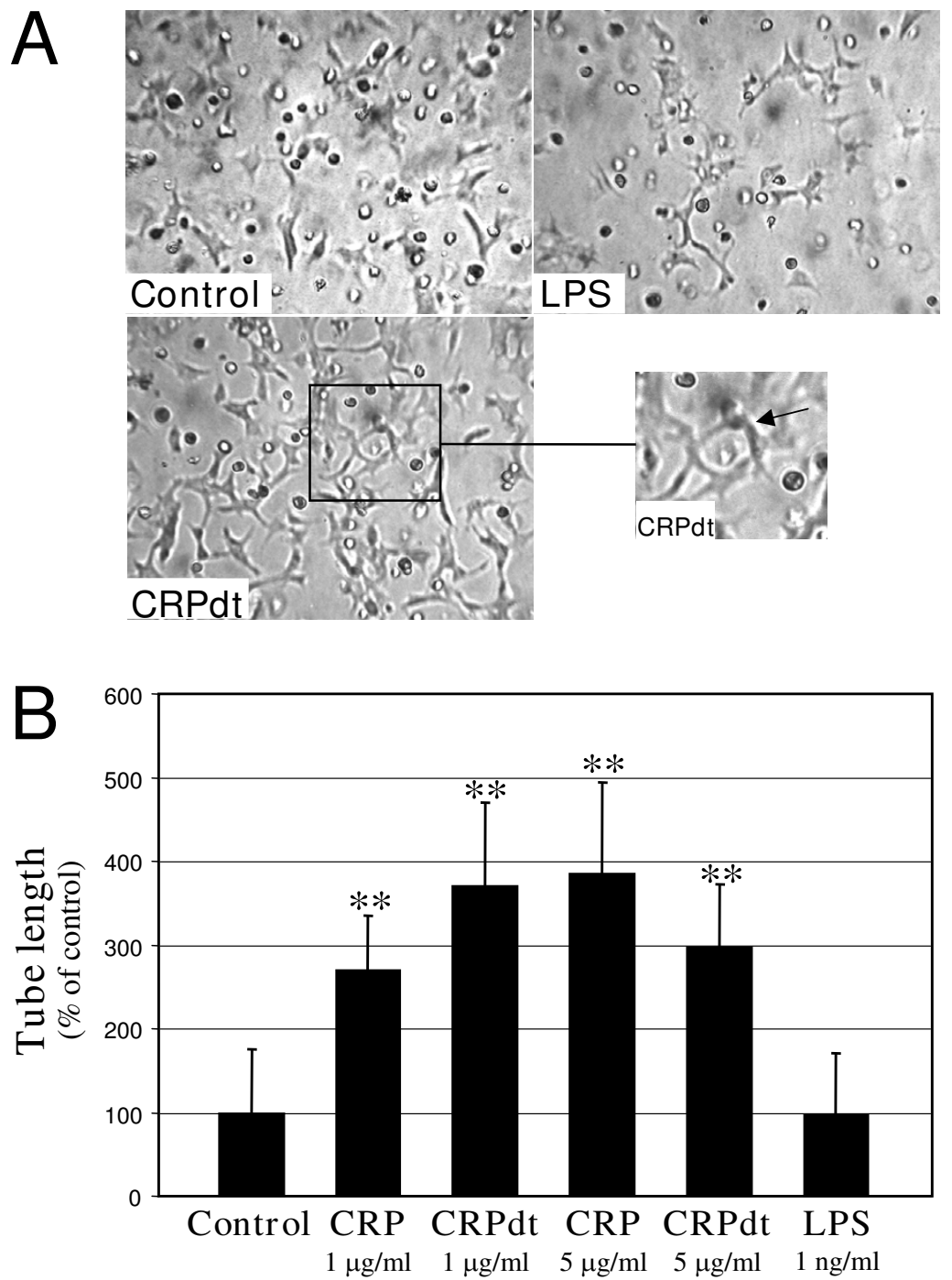

Figure 3

CRP induced tube-like structure formation in HCAEC. A, Representative images from control cells and cells treated with I ng/ $\mathrm{ml} \mathrm{LPS} \mathrm{or} \mathrm{I} \mu \mathrm{g} / \mathrm{ml}$ of detoxified CRP [CRPdt] for $24 \mathrm{~h}$ are shown. B, Bar graph showing tube length as a percentage of control. Experiments were performed at least twice by triplicate. ** indicates a statistically significant difference compared with the control $(p<0.001)$.

iogenic effects of CRP. Interestingly, assays performed using purified LPS at concentrations that were similar to or exceeded those reported in high purity human recombinant CRP from our commercial supplier [43,44] demonstrated no significant effects on BAEC or HCAEC angiogenesis or IL- 8 gene activation. This is in agreement with the recent findings of Dasu et al. who showed that purified CRP was able to activate IL-8, IL-6, IL-1 $\beta$, PAI-1 and eNOS in Toll-like receptor 4 knockout HAEC, indicating that the effects were not due to LPS contamination [43].
In this study, we showed that CRP induces angiogenesis in vitro in two separate sources of primary cultured vascular EC as well as in vivo as judged by an increase in capillary formation in the CAM assay, aortic ring assay and 3DMatrigel. The angiogenic potency of CRPdt was quite strong, being $50-75 \%$ of that demonstrated by our positive control FGF-2 ( $25 \mathrm{ng} / \mathrm{ml}$; comparisons not included). One other study showed previously that CRP induced proliferation of rabbit thoracic EC with a concomitant increase in expression of p-ERK1/2, similar to our own findings [44]. In their study, they controlled for LPS by 

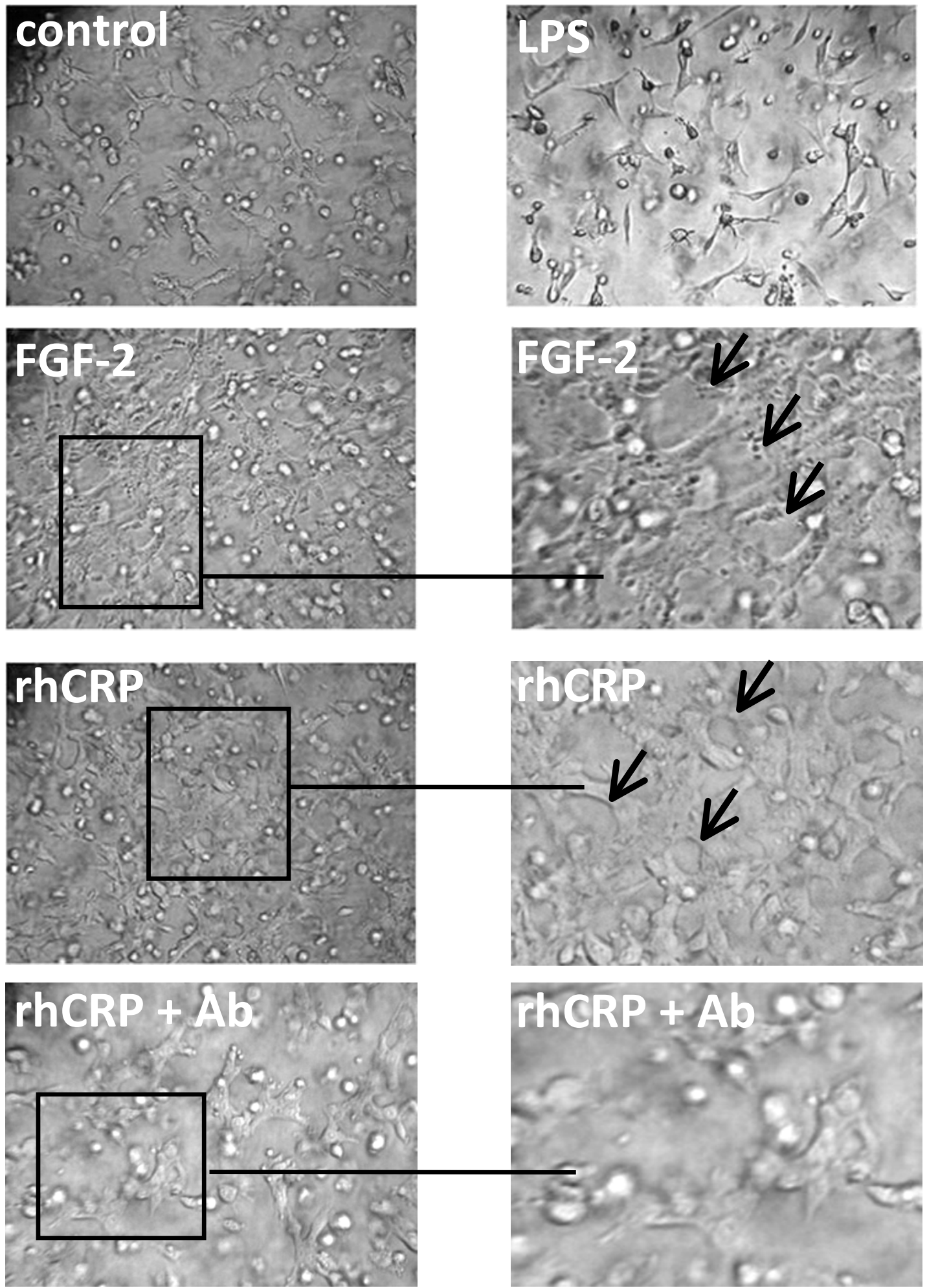

Figure 4

CRP induced tube-like structure formation in BAEC. Representative images from control cells and cells treated with I ng/ml LPS, FGF-2 (25 ng/ml), I $\mu \mathrm{g} / \mathrm{ml}$ of detoxified CRP [CRPdt] or CRP + blocking antibody against CRP for $24 \mathrm{~h}$ are shown. 
A

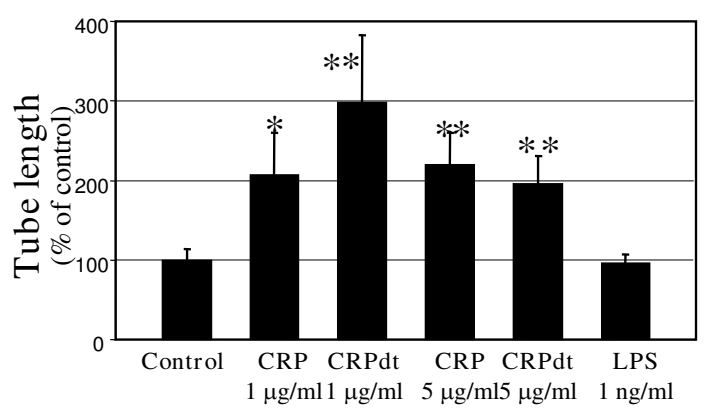

B

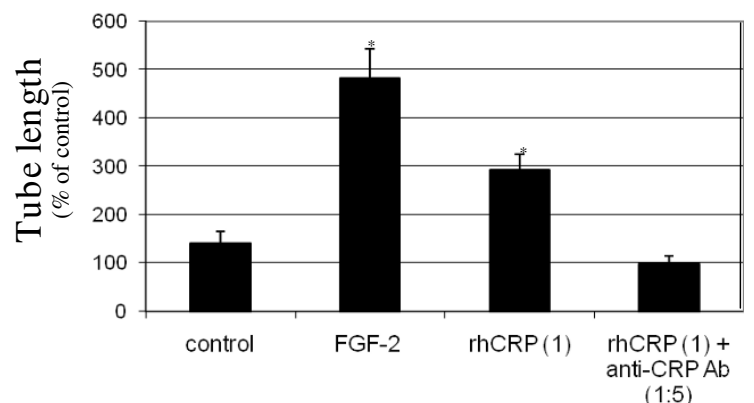

Figure 5

CRP induced tube-like structure formation in BAEC. A, Bar graph showing tube length as a percentage of control. Experiments were performed at least twice by triplicate. B, Bar graphs showing tube length as a percentage of control from cells treated with FGF-2 $(25 \mathrm{ng} / \mathrm{ml}), \mathrm{I} \mu \mathrm{g} / \mathrm{ml}$ of detoxified CRP [CRPdt] or CRP + blocking antibody against CRP for 24 h. * and ** indicate a statistically significant difference compared with the control cells ( $p>0.05$ and 0.00 I respectively.

measuring levels with the Limulus assay which were recorded as $<0.125 \mathrm{EU} / \mathrm{ml}$. The authors, however, found that increased proliferation occurred only at significantly high CRP concentrations of ( $>20 \mu \mathrm{g} / \mathrm{ml})$, and furthermore, they did not consider the effects of azide. In agreement with our findings, Bello et al (2008), showed that CRP increases VEGF-A expression via PI3-kinase and ERK1/2 pathway and thus could play a role in the angiogenesis process [45]. Orozlan et al. found no effects of CRP on HUVEC proliferation although they did not supply data indicating the concentration of CRP used [46]. In our previous studies where we have characterised various types of vascular cells, we have found HUVEC to be the least responsive to pro-angiogenic stimuli including VEGF, FGF-2 and oligosaccharides of hyaluronan; therefore, these results are perhaps not surprising [41]. The fact

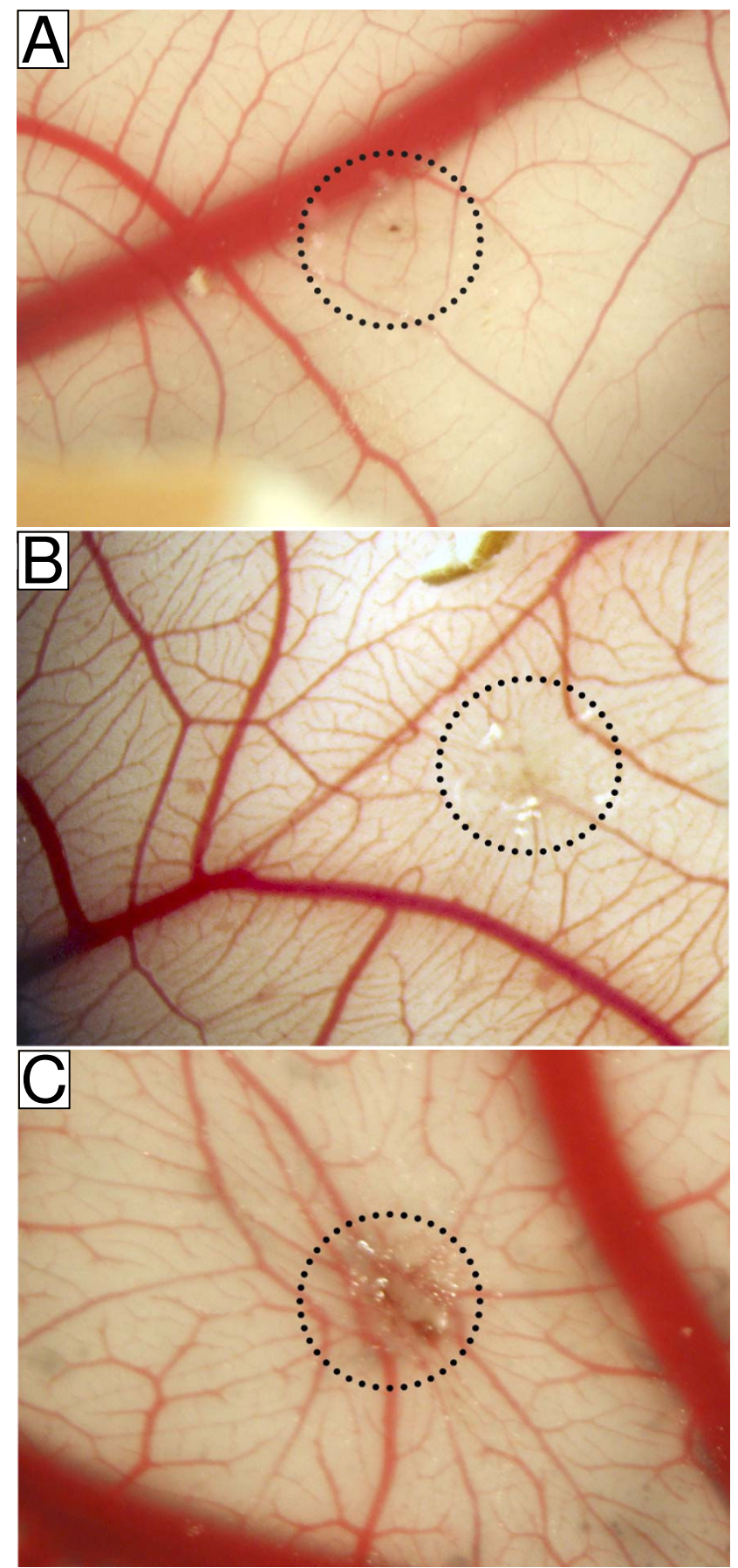

Figure 6

CRP stimulated spoke wheel blood vessel formation in the CAM assay. A, Negative control (score 0.5); B, CRPdttreated (5 $\mu \mathrm{g} / \mathrm{ml}$; score 2.0); C, Positive control, FGF-2treated $(100 \mathrm{ng} / \mathrm{ml})$ (score 3.0). Spoke wheel patterns can be seen in both CRP- and FGF-2-treated samples originating from the pellet (designated by dotted circles). Experiments were performed twice. A representative example of 5 CAM's used per experiment is shown. 
A
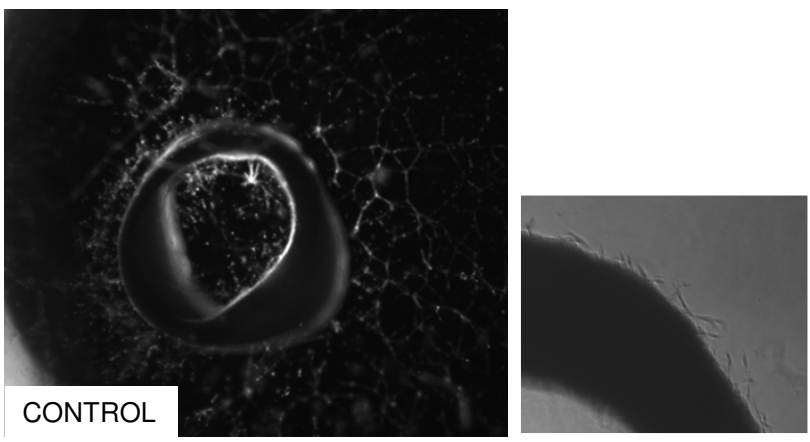

C
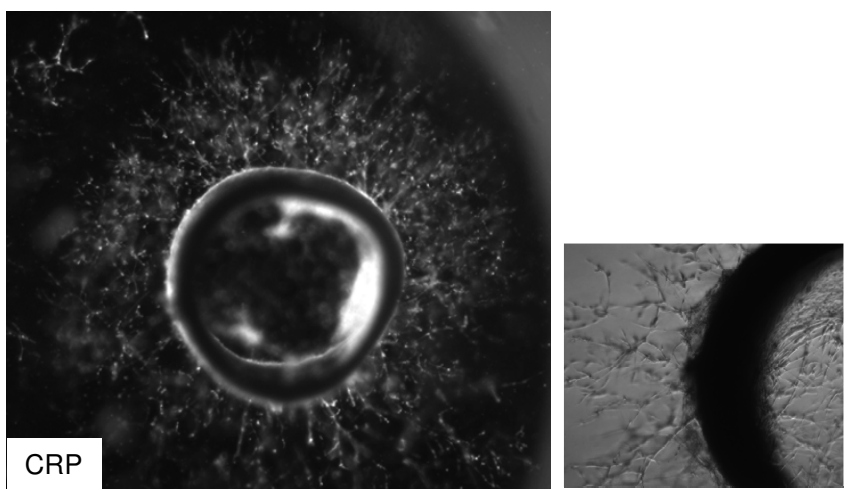
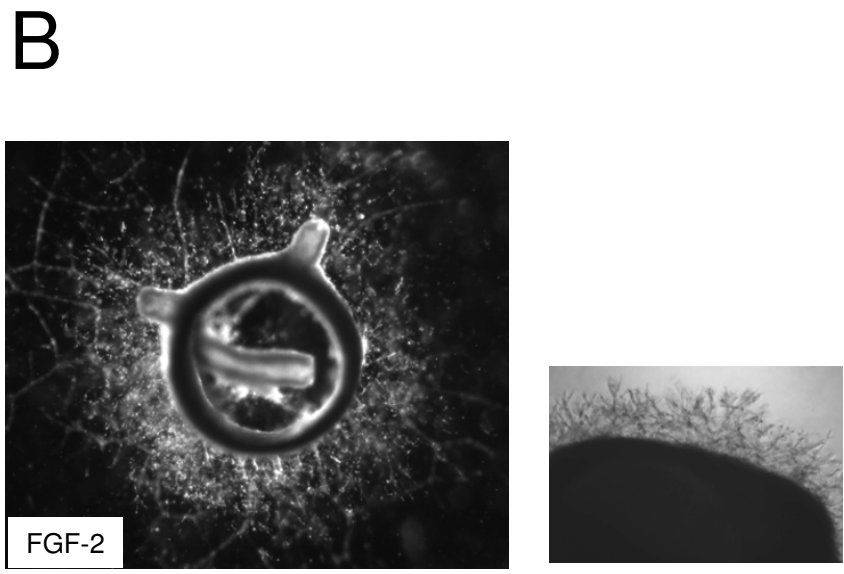

D

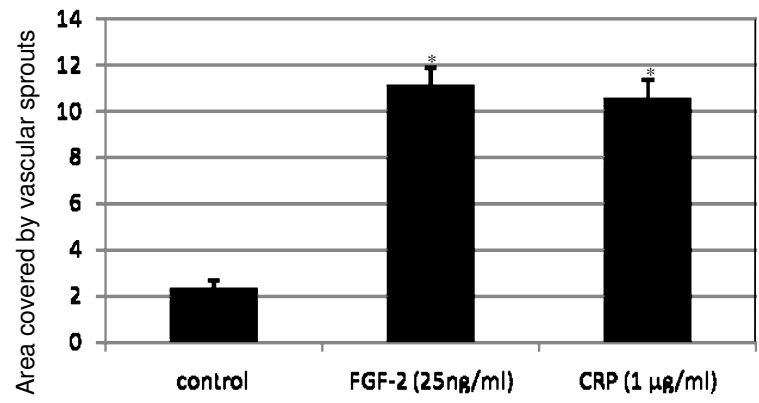

Figure 7

Aortic ring assay. A, control. B, Incubated with FGF-2 (25 ng/ml). C, Incubated with I $\mu \mathrm{g} / \mathrm{ml}$ of detoxified CRP [CRPdt]. D, Bar graphs showing area covered by vascular sprouts in control, FGF-2 $(25 \mathrm{ng} / \mathrm{ml})$ and CRPdt $(\mathrm{I} \mu \mathrm{g} / \mathrm{ml})$.

that CRP did not stimulate HCAEC proliferation suggests that there may be variability in cellular responses dependent on cell type, and EC have been shown in many studies to be heterogeneous in this regard. Indeed, in contrast to our results, one recent study showed induction of apoptosis in human umbilical EC (HUVEC) incubated with CRP, analyzed by TUNEL and caspase- 3 activity assay and inhibition [47]. However, the above study used $10 \mu \mathrm{g} / \mathrm{ml}$ of CRP in their assay and we observed a pro-angiogenic effect of CRP at 1 and $5 \mu \mathrm{g} / \mathrm{ml}$. Moreover, the apoptotic effect of CRP was demonstrated in HUVEC and cellular response may be dependent on EC origin. In addition, in the same study the authors showed that CRP treatment of monocluclear cells induced production of MMP-9 which is involved in extraclellular matrix degradation, cell migration and release of angiogenic factors necessary to elicit angiogesis $[48,49]$ Verma et al. showed that purified CRP attenuated NO release in human saphenous vein EC, increased apoptosis and inhibited capillary-like tube formation in matrigel at $5-25 \mu \mathrm{g} / \mathrm{ml}$ [32]; however, they did not control for the effects of azide. The same authors also demonstrated that CRP inhibited EC progenitor differentiation, survival and function through a process involving a reduction in NO expression appeared to be carried out without the use of suitable azide and endotoxin controls [50].

Our data showing a potent angiogenic effect of CRP/ CRPdt is strongly backed up by the results of our real-time TaqMan PCR microarrays. Using our specifically designed targeted microfluidity cards, we showed up-regulation of key genes involved in promotion of vascularisation. We found 6 genes up-regulated by CRPdt on HCAEC between 12-72 h. VEGF receptor-2 (KDR), the main receptor mediating both signal transduction and the biologic responses, including angiogenesis, triggered by VEGF in endothelial cells [51], was significantly induced by CRPdt. Up-regulation of this receptor together with growth factors such as PDGF- B involved in cell proliferation and angiogenesis [52], could be one mechanism through 

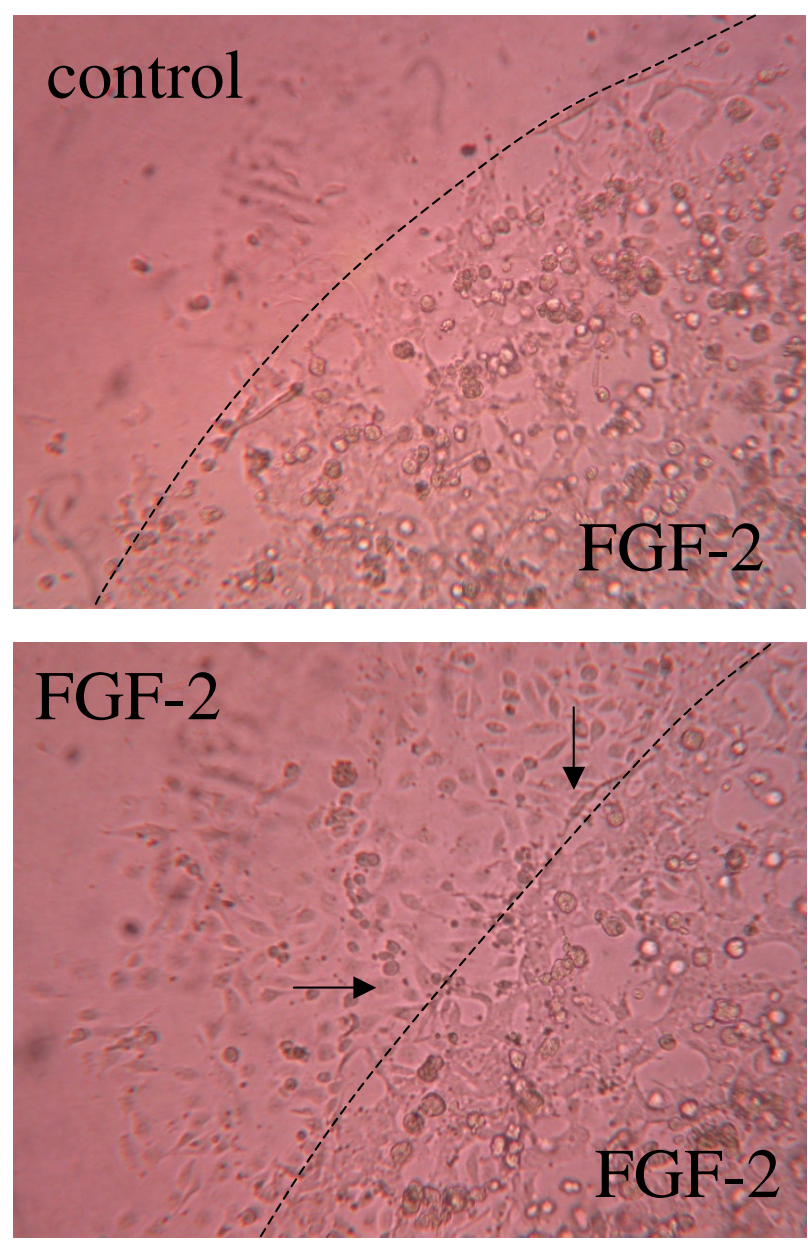
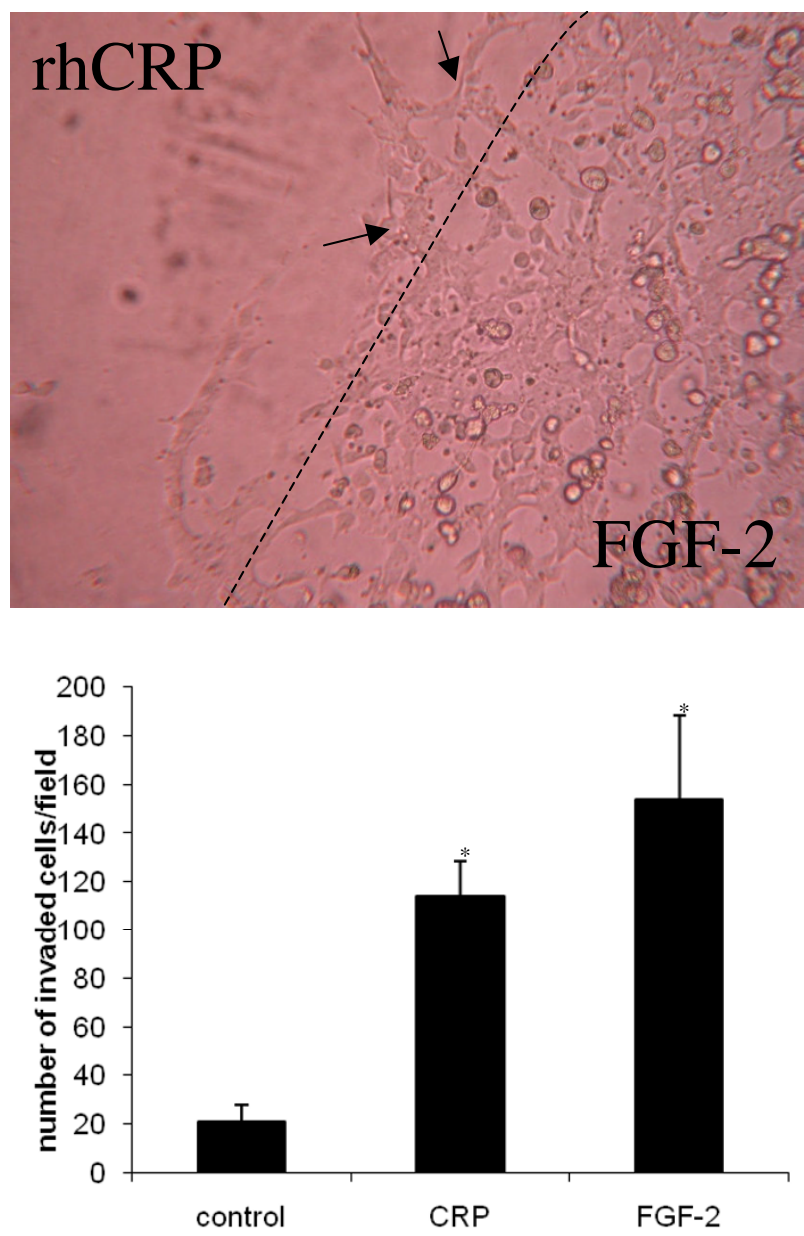

\section{Figure 8}

3D-matrigel invasion assay in control, FGF-2 $(25 \mathrm{ng} / \mathrm{ml})$ (arrows) and CRPdt $(\mathrm{I} \mu \mathrm{g} / \mathrm{ml})$ (arrows). Dotted line marks the interface between the first and the second layer of the matrigel.

which CRP initiates its angiogenic effects. Notch1 was increased after $12 \mathrm{~h}$ of CRP treatment. Notch 1 is required for formation of correct sprouting and branching patterns during VEGF-stimulated angiogenesis in vivo [53]. Recently, cyclic strain was shown to up-regulate Notch1 in human vascular EC and this process was responsible for significantly increased tube-formation in matrigel suggesting a role in development of atherosclerosis [54]. Notch 3 is other member of the Notch family that seems to be critical for vascular cell survival and is required for the arterial identity and maturation of vascular cells $[55,56]$. One particularly novel finding was the up-regulation of CYR61. CYR61 is an extracellular matrix-associated protein expressed within developing vasculature, which promotes angiogenesis both in vitro and in vivo [57]. CYR61 binds directly to the integrin $\alpha_{v} \beta_{3}$ present on activated EC and mediates chemotaxis and tube formation. Finally, ID1, originally identify as a dominant-negative antagonist of the basis helix-loop-helix (HLH) transcription factors has been recently involved in VEGFinduced angiogenesis in human endothelial cells [58]. Future work should be addressed to determine the expression, localization and relevance of these proteins in angiogenic regions of developing complicated atherosclerotic lesions.

This discussion would not be complete without a brief mention of the recently characterised modified CRP (mCRP). Evidence has emerged that native pentametric CRP can change its structural conformation following separation into monomers. Following re-arrangement, formation of the mCRP sub-unit has increased binding affinity for plasma membranes, and has been shown to be preferentially expressed in tissues [59]. Recent evidence suggest that mCRP may be a significantly weaker stimulator of pro-inflammatory molecules in vascular EC (e.g. IL8, PAI- 1 and prostaglandin F1- $\alpha$ ), and hence atherogenic effects [60]. However, it is important to remember that 

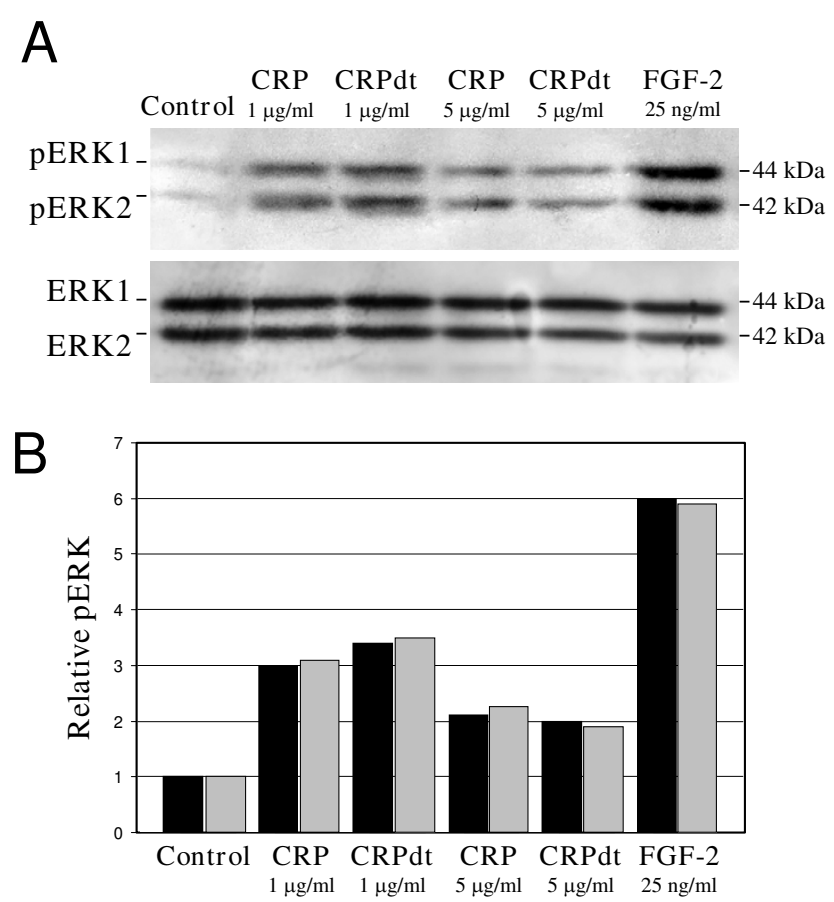

Figure 9

CRP activated ERKI/2 in HCAEC. A, Western blot showing the effect of $\mathrm{I}-5 \mu \mathrm{g} / \mathrm{ml}$ CRP (non-detoxified and detoxified CRP [CRPdt]) on phosphorylation of ERKI/2 (pERKI/2) in HCAEC. The increase was similar to that produced by FGF-2 $(25 \mathrm{ng} / \mathrm{ml})$. Total ERKI/2 protein levels were used as a loading control. Experiments were performed at least twice and a representative example is shown. $B$, quantitative densitometic analysis of the blot shown in A. (ERK-I [black bars]; ERK-2 [shaded bars]).

native CRP can be found at high concentration in many hospital patients and most of them do not develop acute cardiovascular events. This suggests that cardiovascular effects of CRP if indeed important maybe due to its modified form.

\section{Conclusion}

Our findings strongly suggest an important role for CRP in modulation of angiogenesis and as such, CRP could promote the formation of intimal neovessels of complicated unstable plaques increasing the likelihood of rupture. The distribution of both native and mCRP should be investigated in complicated atherosclerotic plaques and further studies should aim to identify the mechanisms of cell binding and intracellular mechanisms leading to cellular activation.

\section{Methods \\ Materials}

Human coronary artery EC (HCAEC), EC basal medium and growth factor supplements were bought from TCS CellWorks (Botolph Claydon, UK). HCAEC were used between passage 2 and 6, and cultured according to the manufacturer's instructions. Bovine aortic EC (BAEC) were isolated from bovine arteries, seeded in DMEM (Invitrogen) supplemented with $15 \%$ foetal calf serum, containing penicillin and $100 \mu \mathrm{g} / \mathrm{ml}$ streptomycin (SigmaAldrich, St Louis, MO) routinely cultured as described elsewhere, and used between passage 3 and $6 .{ }^{41}$ Human recombinant CRP was obtained from Calbiochem (San Diego, California, USA). Sodium azide, phenylmethylsulfonyl fluoride (PMSF), leupeptin and lipopolysaccharide (LPS; 20,000 endotoxin units (EU)/mg LPS) were purchased from Sigma-Aldrich. Growth factor-reduced Matrigel was bought from Beckton Dickinson (BD Biosciences, San Jose, CA) and recombinant basic fibroblast growth factor (FGF-2) was from R\&D systems (Minneapolis, MN). Antibody to CRP was purchased from Sigma. Experimental research carried on animals followed internationally recognized guidelines and was approved by local ethical committe at Centro de Investigación Cardiovascular, CSIC-ICCC, Hospital de la Santa Creu i Sant Pau, Barcelona, Spain.

\section{CRP purity testing and endotoxin removal}

CRP purity was checked by SDS-PAGE followed by Coomassie blue staining where CRP was identified as a single band [57]. Endotoxin concentrations in CRP sam-

Table I: Angiogenesis-related genes modulated by CRP in HCAEC

\begin{tabular}{|c|c|c|c|}
\hline Gene name & $\begin{array}{l}\text { Fold-increase (time) } \\
\text { Experiment \#I }\end{array}$ & $\begin{array}{l}\text { Fold-increase (time) } \\
\text { Experiment \#2 }\end{array}$ & Gene function \\
\hline KDR/FIk-I/VEGFR2 & $1.53(12 \mathrm{~h})$ & $1.94(24 \mathrm{~h})$ & Cell survival, proliferation and angiogenesis 44 \\
\hline PDGF-B & $2.44(24 \mathrm{~h})$ & $3.94(12 \mathrm{~h})$ & Proliferation and angiogenesis 45 \\
\hline Notch I & $3.28(12 \mathrm{~h})$ & $1.97(12 \mathrm{~h})$ & Angiogenesis (spreading and branching) 46 \\
\hline Notch3 & $2.03(24 \mathrm{~h})$ & $4.46(72 \mathrm{~h})$ & Vascular cell identity and survival 47,48 \\
\hline CYR6I/CCNI & $4.94(72 \mathrm{~h})$ & $3.91(12 \mathrm{~h})$ & Connective tissue growth factor 49 \\
\hline IDI & $2.65(24 h)$ & $1.94(12 \mathrm{~h})$ & Cell cycle and angiogenesis 50 \\
\hline
\end{tabular}

PDGF, Platelet-derived growth factor; KDR: kinase-insert domain receptor; VEGFR2, vascular endothelial cell growth factor receptor-2; CYR6I, Cysteine-rich angiogenic inducer 6; IDI, Inhibitor of DNA binding/differentiation-I. 
ples were measured using the Limulus assay (sensitivity < 0.125 EU/ml, Chromogenix AB, Mölndal, Sweden). Purified LPS was included in control experiments at concentrations that exceeded those reported to be found in human recombinant CRP from Calbiochem $(1 \mathrm{ng} / \mathrm{ml})$ $[58,59]$. In all of the experiments CRP treated with detoxigel columns (CRPdt) containing immobilized polymyxin $\mathrm{B}$ was used to ensure the absence of pyrogens (Affinit$\mathrm{yPak}^{\mathrm{TM}}$ detoxi-Gel ${ }^{\mathrm{TM}}$ column; Pierce, Rockford, IL). Removal of LPS was confirmed using the limulus assay. Non-detoxified native CRP preparations were used for comparison. To analyze the possible effect of sodium azide present in the CRP preparations, cells were incubated with $0.00005-0.0005 \%$ sodium azide, equivalent to that found in $1-10 \mu \mathrm{g} / \mathrm{ml}$ CRP.

\section{Response testing of HCAEC and BAEC to CRP: choice of CRP concentration}

In this work, we investigated the effects of CRP at concentrations ranging from $1-10 \mu \mathrm{g} / \mathrm{ml}$. Published data suggests that normal circulating levels of CRP are $<1 \mu \mathrm{g} / \mathrm{ml}$. In pathological situations, such as in patients with inflammation, and particularly in those with advanced unstable atherosclerosis, CRP levels increase. CRP levels of $<1,1$ to 3 , and $>3 \mu \mathrm{g} / \mathrm{ml}$ correspond to low-, moderate-, and highrisk groups for future cardiovascular events [21].

\section{Chemotaxis assay}

BAEC or HCAEC were seeded at $7.3 \times 10^{4}$ cells $/ \mathrm{ml}$ in 100 $\mu \mathrm{l}$ of serum poor medium on Transwell porous membranes (Costar; $8-\mu \mathrm{m}$ pore filter) plated into a 24 -well plate. Basal medium supplemented with $0.1 \%$ FBS and CRP $(1-5 \mu \mathrm{g} / \mathrm{ml})$. We also incubed cells with CRP pretreated with antibody to CRP in order to confirm the effect was due to CRP protein itself. FGF-2 $(25 \mathrm{ng} / \mathrm{ml})$ was used as a positive control. For each experimental condition, cells were treated in duplicate. After $24 \mathrm{~h}$ incubation, the cells which did not migrate on the upper surface of the membrane were removed with a cotton swab soaked with PBS then wiped with a dried cotton swab. The cells which had migrated were fixed with $4 \%$ paraformaldehyde, left to air dry, stained with Giemsa and counted with an optical microscope. All experiments were performed at least three times.

\section{Effect of CRP on BAEC and HCAEC proliferation}

BAEC were seeded in complete medium at a concentration of $2 \times 10^{4}$ cells $/ \mathrm{ml}(2 \mathrm{ml}$ per well) in 6 -well plates. HCAEC were seeded in complete medium at a concentration of $2 \times 10^{4}$ cells $/ \mathrm{ml}$ per well in 24 -well plates. After attachment $(4 \mathrm{~h})$ the medium was replaced with serum poor medium (SPM), containing 2.5\% FBS (BAEC) and $5 \%$ FBS (HCAEC) in which the cells grew at a significantly reduced rate. CRP was added at concentrations ranging from $1-5 \mu \mathrm{g} / \mathrm{ml}$. After $72 \mathrm{~h}$ incubation, cells were washed with PBS without $\mathrm{Ca}^{2+}$ and $\mathrm{Mg}^{2+}$, detached with trypsin then counted using a Coulter counter (Coulter Electronics, Hialeah, FL). All experiments were performed at least three times.

\section{Tube-like structure formation assay}

BAEC or HCAEC $\left(2 \times 10^{6}\right.$ cells $\left./ \mathrm{ml}\right)$ were cultured in complete medium and mixed in an equal volume with $40 \mu \mathrm{l}$ of growth factor-reduced Matrigel $(10 \mathrm{mg} / \mathrm{ml})$ with or without CRP at concentrations varying between 1 and 5 $\mu \mathrm{g} / \mathrm{ml}$. We also incubed cells with CRP pre-treated with antibody to CRP in order to confirm the effect was due to CRP protein itself. FGF-2 $(25 \mathrm{ng} / \mathrm{ml})$ was used as a positive control. Half of the mixture was allowed to polymerise as three-dimensional droplets in 48-well plates and each experimental condition was carried out in duplicate. After polymerization $(1 \mathrm{~h})$, each spot of Matrigel was bathed in $500 \mu \mathrm{l}$ of complete medium for $24 \mathrm{~h}$. The cells were then fixed with $4 \%$ paraformaldehyde for $10 \mathrm{~min}$. the total length of tube-like structures was measured by light microscopy after $48 \mathrm{~h}$ in a double-blinded fashion. All experiments were performed at least three times.

\section{Chick Chorioallantoic membrane (CAM) assay}

The angiogenic activity of compounds was determined in the chick chorioallantoic assay (CAM) as described previously [61]. CRPdt (5 $\mu \mathrm{g})$ was applied to the membrane (10 membranes per treatment) and the resultant angiogenesis scored as 0 , negative; 0.5 , change in vessel architecture; 1 , partial spoke wheel $(1 / 3$ of circumference exhibits directional angiogenesis); 2, spoke wheel; 3 or greater, strong and full spoke wheel. Control membranes had the equivalent concentration of sodium azide added. To photograph the membrane, $2 \mathrm{~cm}^{3}$ of a $50 \%$ emulsion of aqueous paraffin oil containing $2 \%$ Tween- 80 was injected at the site of application and photographed using a Leitz dissecting microscope. FGF-2 (100 ng) was used as a positive control. All experiments were performed at least three times. This approach enabled calculation of an accumulated response in each group. All experiments were performed at least five times and statistical differences were determined by the Mann-Whitney $U$ test and the data is expressed as a median value $(\mathrm{m})$.

\section{Rat aortic ring sprouting assay}

Aortic ring assays were performed as described with minor modifications [62]. Aortas were removed from adult male Wistar rats $(250 \mathrm{~g})$ and immediately placed in ice cold EC growth medium (ECGM) supplemeted with 1\% PBS. After removing the fibro-adipose tissue, arteries were cut into $1 \mathrm{~mm}$ long cross section, rinsed in PBS and placed on the Matrigel-coated wells. Artery rings were covered with addition layer of Matrigel $(10 \mathrm{mg} / \mathrm{ml})$ and incubated with ECGM at $37^{\circ} \mathrm{C}$ in $5 \% \mathrm{CO}_{2}$. After 24 hours incubation, medium was replaced with medium ECGM with or with- 
out CRP $(1 \mu \mathrm{g} / \mathrm{ml})$. FGF-2 $(25 \mathrm{ng} / \mathrm{ml})$ was used as a positive. After 6 days, images of aortic rings were taken using a Leica DMIRE microscope and the outgrowth area delineated and measured. Sprouts was measuring using Image software and analyzed by calculating the area occupied by microvessel sprouts eminating from the arterial ring.

\section{Invasion assay in a 3D-Matrige ${ }^{\mathrm{TM}}$ matrix}

To assess the effect of CRP on EC invasion into a second Matrigel $^{\mathrm{TM}}$ layer the first layer was formed in $0.1 \% \mathrm{FCS}$ and $25 \mathrm{ng} / \mathrm{ml}$ of FGF-2 and tube-like structures allowed to form over $24 \mathrm{~h}$. Then a second layer of Matrige ${ }^{\mathrm{TM}}$ was formed around the first layer containing $1 \mu \mathrm{g} / \mathrm{ml}$ of CRP. After polymerisation, these wells were incubated with 500 $\mu \mathrm{l}$ of medium containing $0.1 \%$ FCS with or without $1 \mu \mathrm{g} /$ $\mathrm{ml}$ CRP or with $25 \mathrm{ng} / \mathrm{ml}$ FGF-2 as a positive control for a further $24 \mathrm{~h}$. The wells were fixed with 4\% PFA and the number of invading cells was quantified by visualising the border with the Matrigel ${ }^{\mathrm{TM}}$ using phase contrast microscopy and counting the number of cells in three different areas of the second matrix layer. Experiments were performed in triplicate wells.

\section{RNA extraction, cDNA synthesis and TaqMan Low- Density Array}

Our pilot studies demonstrated up-regulation of IL-8, (used as a marker of EC activation) by CRP [60], at concentrations ranging from $1-25 \mu \mathrm{g} / \mathrm{ml}$. ECs (BAEC and HCAEC) we incubated for 4-72 $\mathrm{h}$ in presence or absence of CRP and IL-8 expression was assessed by real-Time PCR. IL-8 expression was not abrogated by pre-incubation with polymyxin B $(5 \mu \mathrm{g} / \mathrm{ml})$ used to exclude the potential effect of traces of LPS potentially present in CRP preparations. RNA was isolated from semi-confluent cultured HCAEC in SPM following treatment for 4-72 h with CRP $\left(5 \mu \mathrm{g} / \mathrm{ml}\right.$ ) or sodium azide alone using the RNeasy ${ }^{\mathrm{TM}} \mathrm{Mini}$ Kit (Qiagen) according to the manufacturer's instructions. The TaqMan low-density array (Applied Biosystems) consists of 48 selected TaqMan primers and probes (see Additional file 1) preconfigured in a 384-well format and spotted on a microfluidic card (2 replicates per assay). Control HCAEC and those treated with CRP for different times ( $4 \mathrm{~h}, 12 \mathrm{~h}, 24 \mathrm{~h}$ and $72 \mathrm{~h}$ ) were prepared in triplicate, then the three wells were pooled together. $50 \mu \mathrm{l}$ of cDNA from each sample was loaded on the TaqMan LowDensity Array as described [5]. Real-time RT-PCR amplifications were run on an ABI Prism ${ }^{\circledR} 7900$ Ht sequence Detection System (Applied Biosystems) with a TaqMan Low-Density Array Upgrade. Thermal cycling conditions were as follows: $2 \mathrm{~min}$ at $50^{\circ} \mathrm{C} ; 10 \mathrm{~min}$ at $95^{\circ} \mathrm{C} ; 40$ cycles of denaturation at $95^{\circ} \mathrm{C}$ for 15 seconds; and annealing and extension at $60^{\circ} \mathrm{C}$ for $1 \mathrm{~min}$. The experiment was performed twice and only genes up-regulated in both experiments were considered validated.

\section{Western blotting}

BAEC or HCAEC were seeded in complete medium in 24well plates. After $48 \mathrm{~h}$ incubation, the medium was replaced with SPM for $48 \mathrm{~h}$ before addition of CRP (1-5 $\mu \mathrm{g} / \mathrm{ml}$ ) or $25 \mathrm{ng} / \mathrm{ml} \mathrm{FGF-2} \mathrm{for} 8 \mathrm{~min}$ and western blotting was carried out using standard process as previously described [41]. Proteins were electroblotted (Hoefer, Bucks, UK) onto nitrocellulose filters (1 h) and the filters were blocked for $1 \mathrm{~h}$ at room temperature in TBS-Tween (pH 7.4) containing 1\% BSA. Filters were stained with the following primary antibodies diluted in the appropriate blocking buffer, overnight at $4{ }^{\circ} \mathrm{C}$ on a rotating shaker: rabbit monoclonal antibodies to ERK1/2 (1:1000) and mouse monoclonal antibodies to phosphorylated ERK1/ 2 (P-ERK1/2, 1:1000) from Santa Cruz Biotechnology. After washing filters were stained with either goat antirabbit or rabbit anti-mouse horse-radish peroxidase-conjugated secondary antibodies (1:1000, $1 \mathrm{~h}$, room temperature). Proteins were visualized using ECL chemiluminescent detection. All experiments were performed at least twice.

\section{Authors' contributions}

MMT carried out RNA extraction, cDNA synthesis and TaqMan Low-Density Arrays. SM and MGO performed all cell culture studies, migration and proliferation assays. AL performed chemotaxis assays. DW carried out Chick Chorioallantoic membrane (CAM) assays. CR carried out pilot studies on the effect of CRP on IL-8. JK analysed all the results. MS, LB, JMG and JK participated in the design of the study and preparation of the manuscript. All authors read and approved the manuscript.

\section{Additional material}

\section{Additional file 1}

Applied bio systems codes. Click here for file

[http://www.biomedcentral.com/content/supplementary/14712121-9-47-S1.doc]

\section{Acknowledgements}

This work was supported by grants: Marie Curie Reintegration Grant ERG01152 and SAF 2006-0768I from the Ministerio de Educación y Ciencia (MEC) to JK. We are grateful for the support provided by Fundación BBVA to Professor Slevin in the form of a Chair in Clinical Biomedicine at the ICCC, St Pau Hospital, Barcelona, Spain.

\section{References}

I. Glass CK, Witztum JL: Atherosclerosis. the road ahead. Cell 200I, 104(4):503-5I6.

2. Ross R: Atherosclerosis-an inflammatory disease. NEngl J Med 1999, 340(2): II5-126.

3. Libby P: Inflammation in atherosclerosis. Nature 2002, 420(69 I 7):868-874. 
4. Krupinski J, Stroemer P, Slevin M, Marti E, Kumar P, Rubio F: Threedimensional structure and survival of newly formed blood vessels after focal cerebral ischemia. Neuroreport 2003, |4(8): | |7|-|| 76.

5. Krupinski J, Turu MM, Martinez-Gonzalez J, Carvajal A, Juan-Babot JO, Iborra E, Slevin M, Rubio F, Badimon L: Endogenous expression of C-reactive protein is increased in active (ulcerated noncomplicated) human carotid artery plaques. Stroke 2006, 37(5): $1200-1204$.

6. Issa R, AIQteishat A, Mitsios N, Saka M, Krupinski J, Tarkowski E, Gaffney J, Slevin M, Kumar S, Kumar P: Expression of basic fibroblast growth factor mRNA and protein in the human brain following ischaemic stroke. Angiogenesis 2005, 8(I):53-62.

7. Moulton KS: Plaque angiogenesis: its functions and regulation. Cold Spring Harb Symp Quant Biol 2002, 67:471 -482.

8. Mofidi R, Crotty TB, McCarthy P, Sheehan SJ, Mehigan D, Keaveny TV: Association between plaque instability, angiogenesis and symptomatic carotid occlusive disease. $\mathrm{Br}$ J Surg $200 \mathrm{I}$ 88(7):945-950.

9. Folkman J: Angiogenesis in cancer, vascular, rheumatoid and other disease. Nat Med I995, I(I):27-3I.

10. Slevin M, Elasbali AB, Miguel Turu M, Krupinski J, Badimon L, Gaffney $\mathrm{J}$ : Identification of differential protein expression associated with development of unstable human carotid plaques. $\mathrm{Am} J$ Pathol 2006, I68(3): 1004-102I.

II. Blake G], Ridker PM: C-reactive protein: a surrogate risk marker or mediator of atherothrombosis? Am J Physiol Regul Integr Comp Physiol 2003, 285(5):R I 250-1252.

12. Blake G], Ridker PM: C-reactive protein and other inflammatory risk markers in acute coronary syndromes. J Am Coll Cardiol 2003, 4 I (4 Suppl S):37S-42S.

13. Danesh J, Wheeler JG, Hirschfield GM, Eda S, Eiriksdottir G, Rumley A, Lowe GD, Pepys MB, Gudnason V: C-reactive protein and other circulating markers of inflammation in the prediction of coronary heart disease. N Engl J Med 2004, 350(14): I387-1397.

14. Di Napoli M, Papa F, Bocola V: C-reactive protein in ischemic stroke: an independent prognostic factor. Stroke 200I, 32(4):917-924.

15. Gabay C, Kushner I: Acute-phase proteins and other systemic responses to inflammation. N Engl J Med 1999, 340(6):448-454.

16. Hirschfield GM, Pepys MB: C-reactive protein and cardiovascular disease: new insights from an old molecule. Qjm 2003, 96(I I):793-807.

17. Shrive AK, Cheetham GM, Holden D, Myles DA, Turnell WG, Volanakis JE, Pepys MB, Bloomer AC, Greenhough TJ: Three dimensional structure of human C-reactive protein. Nat Struct Bio 1996, 3(4):346-354.

18. Thompson D, Pepys MB, Wood SP: The physiological structure of human C-reactive protein and its complex with phosphocholine. Structure 1999, 7(2):169-177.

19. Torzewski J, Torzewski M, Bowyer DE, Frohlich M, Koenig W, Waltenberger J, Fitzsimmons $C$, Hombach V: C-reactive protein frequently colocalizes with the terminal complement complex in the intima of early atherosclerotic lesions of human coronary arteries. Arterioscler Thromb Vasc Biol 1998 18(9):1386-1392.

20. Jabs WJ, Theissing E, Nitschke M, Bechtel JF, Duchrow M, Mohamed $\mathrm{S}$, Jahrbeck B, Sievers HH, Steinhoff J, Bartels C: Local generation of C-reactive protein in diseased coronary artery venous bypass grafts and normal vascular tissue. Circulation 2003 I08(I 2): | 428-|43|.

21. Ridker PM: Clinical application of C-reactive protein for cardiovascular disease detection and prevention. Circulation 2003 107(3):363-369.

22. Ridker PM, Rifai N, Rose L, Buring JE, Cook NR: Comparison of Creactive protein and low-density lipoprotein cholesterol levels in the prediction of first cardiovascular events. N Engl J Med 2002, 347(20): 1557-1565.

23. Yeh ET, Willerson JT: Coming of age of C-reactive protein: using inflammation markers in cardiology. Circulation 2003, 107(3):370-37I.

24. Meer IM Van Der, De Maat MP, Hak AE, Kiliaan AJ, Del Sol Al, Kuip DA Van Der, Nijhuis RL, Hofman A, Witteman JC: C-reactive protein predicts progression of atherosclerosis measured at var- ious sites in the arterial tree: the Rotterdam Study. Stroke 2002, 33( I 2):2750-2755.

25. Pepys MB, Hirschfield GM: C-reactive protein: a critical update. J Clin Invest 2003, I I I( I 2): |805-I8|2.

26. Szmitko PE, Wang CH, Weisel RD, de Almeida JR, Anderson TJ, Verma S: New markers of inflammation and endothelial cell activation: Part I. Circulation 2003, 108(16):1917-1923.

27. Torzewski M, Rist C, Mortensen RF, Zwaka TP, Bienek M, Waltenberger J, Koenig W, Schmitz G, Hombach V, Torzewski J: C-reactive protein in the arterial intima: role of $\mathrm{C}$-reactive protein receptor-dependent monocyte recruitment in atherogenesis. Arterioscler Thromb Vasc Biol 2000, 20(9):2094-2099.

28. Zwaka TP, Hombach V, Torzewski J: C-reactive protein-mediated low density lipoprotein uptake by macrophages: implications for atherosclerosis. Circulation 200 I, 103(9): I I94-I I 97.

29. Pasceri V, Willerson JT, Yeh ET: Direct proinflammatory effect of C-reactive protein on human endothelial cells. Circulation 2000, 102(18):2165-2168

30. Verma S, Wang CH, Li SH, Dumont AS, Fedak PW, Badiwala MV, Dhillon B, Weisel RD, Li RK, Mickle DA, Stewart DJ: A self-fulfilling prophecy: $C$-reactive protein attenuates nitric oxide production and inhibits angiogenesis. Circulation 2002, 106(8):9|3-919.

31. Verma S, Li SH, Badiwala MV, Weisel RD, Fedak PW, Li RK, Dhillon $B$, Mickle DA: Endothelin antagonism and interleukin- 6 inhibition attenuate the proatherogenic effects of $C$-reactive protein. Circulation 2002, 105(16): 1890-1896.

32. Wang $\mathrm{CH}$, Li SH, Weisel RD, Fedak PW, Dumont AS, Szmitko P, Li RK, Mickle DA, Verma S: C-reactive protein upregulates angiotensin type I receptors in vascular smooth muscle. Circulation 2003, 107(13): 1783-1790.

33. Doronzo G, Russo I, Mattiello L, Trovati M, Anfossi G: C-reactive protein increases matrix metalloproteinase-2 expression and activity in cultured human vascular smooth muscle cells. J Lab Clin Med 2005, I46(5):287-298.

34. Montero I, Orbe J, Varo N, Beloqui O, Monreal JI, Rodriguez JA, Diez J, Libby P, Paramo JA: C-reactive protein induces matrix metalloproteinase- $\mathrm{I}$ and -10 in human endothelial cells: implications for clinical and subclinical atherosclerosis. J Am Coll Cardiol 2006, 47(7): 1369-1378.

35. Abe N, Osanai T, Fujiwara T, Kameda K, Matsunaga T, Okumura K: C-reactive protein-induced upregulation of extracellular matrix metalloproteinase inducer in macrophages: inhibitory effect of fluvastatin. Life Sci 2006, 78(9): 102I-1028.

36. Wolbink GJ, Brouwer MC, Buysmann S, ten Berge IJ, Hack CE: CRP. mediated activation of complement in vivo: assessment by measuring circulating complement-C-reactive protein complexes. J Immunol 1996, I 57(I):473-479.

37. Devaraj S, Xu DY, Jialal I: C-reactive protein increases plasminogen activator inhibitor-I expression and activity in human aortic endothelial cells: implications for the metabolic syndrome and atherothrombosis. Circulation 2003, I07(3):398-404.

38. Liang YJ, Shyu KG, Wang BW, Lai LP: C-reactive protein activates the nuclear factor-kappaB pathway and induces vascular cell adhesion molecule-I expression through CD32 in human umbilical vein endothelial cells and aortic endothelial cells. Mol Cell Cardiol 2006, 40(3):4I2-420.

39. Liu C, Wang S, Deb A, Nath KA, Katusic ZS, McConnell JP, Caplice NM: Proapoptotic, antimigratory, antiproliferative, and antiangiogenic effects of commercial C-reactive protein on various human endothelial cell types in vitro: implications of contaminating presence of sodium azide in commercial preparation. Circ Res 2005, 97(2): |35-| 43.

40. Taylor KE, Giddings JC, Berg CW van den: C-reactive proteininduced in vitro endothelial cell activation is an artefact caused by azide and lipopolysaccharide. Arterioscler Thromb Vasc Biol 2005, 25(6): I225-1230.

4I. Slevin M, Kumar S, Gaffney I: Angiogenic oligosaccharides of hyaluronan induce multiple signaling pathways affecting vascular endothelial cell mitogenic and wound healing responses. J Biol Chem 2002, 277(43):4I046-4I.

42. Pepys MB, Hawkins PN, Kahan MC, Tennent GA, Gallimore JR, Graham D, Sabin CA, Zychlinsky A, de Diego J: Proinflammatory effects of bacterial recombinant human $C$-reactive protein are caused by contamination with bacterial products, not by C-reactive protein itself. Circ Res 2005, 97(II):e97-I03. 
43. Dasu MR, Devaraj S, Du Clos TW, Jialal I: The biological effects of CRP are not attributable to endotoxin contamination: evidence from TLR4 knockdown human aortic endothelial cells. J Lipid Res 2007, 48(3):509-5I 2.

44. Cirillo P, Golino P, Calabro P, Cali G, Ragni M, De Rosa S, Cimmino G, Pacileo M, De Palma R, Forte L, Gargiulo A, Corigliano FG, Angri V, Spagnuolo R, Nitsch L, Chiariello M: C-reactive protein induces tissue factor expression and promotes smooth muscle and endothelial cell proliferation. Cardiovasc Res 2005, 68(I):47-55.

45. Bello G, Cailotto F, Hanriot D, Kolopp-Sarda MN, Latger-Cannard V, Hess K, Zannad F, Longrois D, Ropars A: C-reactive protein (CRP) increases VEGF-A expression in monocytic cells via a PI3-kinase and ERK I/2 signaling dependent pathway. Athersoclerosis 2008 in press.

46. Oroszlan M, Herczenik E, Rugonfalvi-Kiss S, Roos A, Nauta AJ, Daha MR, Gombos I, Karadi I, Romics L, Prohaszka Z, Fust G, Cervenak L: Proinflammatory changes in human umbilical cord vein endothelial cells can be induced neither by native nor by modified CRP. Int Immunol 2006, I 8(6):87I-878.

47. Nabata A, Kuroki M, Ueba $\mathrm{H}$, Hashimoto $\mathrm{S}$, Umemoto $\mathrm{T}$, Wada $\mathrm{H}$ Yasu T, Saito M, Momomura S, Kawakami M: C-reactive protein induces endothelial cell apoptosis and matrix metalloproteinase-9 production in human mononuclear cells: Implications for the destabilization of atherosclerotic plaque. Atherosclerosis 2008, 196:129-135.

48. Arnold SA, Mira E, Muneer S, Korpanty G, Beck AW, Holloway SE, Manes S, Brekken RA: Forced expression of mmp9 rescues the loss of angiogenesis and abrogates metastasis of pancreatic tumors triggered by the absence of host sparc. Exp Biol Med (Maywood) 2008, 233(7):860-73.

49. Conway EM, Zwerts F, Van Eygen V, DeVriese A, Nagai N, Luo W, Collen D: Survivin-dependent angiogenesis in ischemic brain: Molecular mechanisms of hypoxia-induced up-regulation. Am J Pathol 2003, 163:935-946.

50. Verma S, Kuliszewski MA, Li SH, Szmitko PE, Zucco L, Wang CH, Badiwala MV, Mickle DA, Weisel RD, Fedak PW, Stewart DJ, Kutryk MJ: C-reactive protein attenuates endothelial progenitor cell survival, differentiation, and function: further evidence of a mechanistic link between C-reactive protein and cardiovascular disease. Circulation 2004, I09( I7):2058-2067.

5I. Shibuya M: Differential roles of vascular endothelial growth factor receptor-I and receptor-2 in angiogenesis. J Biochem Mol Biol 2006, 39(5):469-478.

52. Battegay EJ, Rupp J, Iruela-Arispe L, Sage EH, Pech M: PDGF-BB modulates endothelial proliferation and angiogenesis in vitro via PDGF beta-receptors. J Cell Biol 1994, I 25(4):917-928.

53. Siekmann AF, Lawson ND: Notch signalling limits angiogenic cell behaviour in developing zebrafish arteries. Nature 2007, 445(7 I 29):78I-784.

54. Morrow D, Cullen JP, Cahill PA, Redmond EM: Cyclic strain regulates the Notch/CBF-I signaling pathway in endothelial cells: role in angiogenic activity. Arterioscler Thromb Vasc Biol 2007. 27(6): 1289-1296

55. Wang W, Prince CZ, Mou Y, Pollman MJ: Notch3 signaling in vascular smooth muscle cells induces c-FLIP expression via ERK/MAPK activation. Resistance to Fas ligand-induced apoptosis. J Biol Chem 2002, 277(24):21723-2I 729.

56. Domenga $\vee$, Fardoux P, Lacombe P, Monet M, Maciazek J, Krebs LT, Klonjkowski B, Berrou E, Mericskay M, Li Z, Tournier-Lasserve E, Gridley T, Joutel A: Notch 3 is required for arterial identity and maturation of vascular smooth muscle cells. Genes Dev 2004, I 8(22):2730-2735.

57. Chen N, Leu SJ, Todorovic V, Lam SC, Lau LF: Identification of a novel integrin alphavbeta3 binding site in CCNI (CYR6I) critical for pro-angiogenic activities in vascular endothelial cells. J Biol Chem 2004, 279(42):44166-44I76.

58. Sakurai D, Tsuchiya N, Yamaguchi A, Okaji Y, Tsuno NH, Kobata T, Takahashi K, Tokunaga K: Crucial role of inhibitor of DNA binding/differentiation in the vascular endothelial growth factorinduced activation and angiogenic processes of human endothelial cells. J Immunol 2004, I 73(9):580I-5809.

59. Ji SR, Wu Y, Zhu L, Potempa LA, Sheng FL, Lu W, Zhao J: Cell membranes and liposomes dissociate C-reactive protein (CRP) to form a new, biologically active structural intermediate: mCRP(m). Faseb / 2007, 21 (I):284-294.
60. Devaraj S, Venugopal S, Jialal I: Native pentameric C-reactive protein displays more potent pro-atherogenic activities in human aortic endothelial cells than modified C-reactive protein. Atherosclerosis 2006, I84(I):48-52.

6I. West DC, Hampson IN, Arnold F, Kumar S: Angiogenesis induced by degradation products of hyaluronic acid. Science 1985, 228(4705): | 324-| 326

62. Mountain DJ, Singh M, Singh K: Downregulation of vegf-d expression by interleukin-I beta in cardiac microvascular endothelial cells is mediated by mapks and pkcalpha/betal. J Cell Physiol 2008, 21 5:337-343.
Publish with BioMed Central and every scientist can read your work free of charge

"BioMed Central will be the most significant development for disseminating the results of biomedical research in our lifetime. "

Sir Paul Nurse, Cancer Research UK

Your research papers will be:

- available free of charge to the entire biomedical community

- peer reviewed and published immediately upon acceptance

- cited in PubMed and archived on PubMed Central

- yours - you keep the copyright 